\title{
Discounting social mine closure planning
}

\author{
M January 3 Circle Consulting, South Africa \\ $\mathbf{H}$ Lee International University of Japan, Japan
}

\begin{abstract}
The mine closure planning process has predominantly focused on the technical and environmental aspects, but there is a growing recognition of the importance of social closure considerations. The current South African legislation too has a strong bias towards environmental and technical closure planning. South African mine closure planning has recently come under the spotlight, partly spurred on by volatile commodity prices, forcing many mines to close or to go on care and maintenance without clear closure plans in place. The resultant impact on local mining communities has been devastating.

This research paper examines the social aspects of mine closure planning of South Deep, a gold mine situated west of Johannesburg in South Africa. South Deep, with its 75-year life-of-mine, faces increased social risks and liabilities because of its proximity to impoverished host communities and other ageing mines. The paper analyses the mine's social closure plans in relation to the South African legislative requirements and the International Council on Mining and Metals (ICMM) guidelines.
\end{abstract}

Keywords: social closure, mine closure planning, South Deep, ICMM, Gold Fields

\section{Introduction}

The mining industry is global in its reach and impact, but the negative environmental and social impacts are disproportionately felt at the local level; a phenomenon sometimes referred to as the paradox of proximity or the resource curse (National Resources Governance Institute 2014; Marais 2013b). Following a wave of mine downscaling and closure in developed countries from 1960s to 1990s mine closure planning came into focus in the late 1990s (World Bank 2002). Over the past 20 years, mine closure has predominantly focused on the technical and environmental mine closure aspects, but there is a growing recognition of the importance of social closure (World Bank 2002). South African mine closure planning has recently come under the spotlight, partly spurred on by volatile commodity prices, forcing many mines to close or to go on care and maintenance without clear closure plans in place. The resultant impact on local mining communities has been devastating.

This research paper examines the social aspects of Gold Fields' South Deep mine closure plan in relation to the legislative requirements and the International Council on Mining and Metals (ICMM) guidelines. The paper stems from research conducted in partial fulfilment of a Master's degree in Business Administration. South Deep was chosen as a case study because it would likely be the last mine operational in an area with a long mining history and dire socio-economic context. Further, in the current context of other mines closing around it, closure issues have come into focus and the mine could be indicative of the risks and challenges other mines would face across mining areas in South Africa. The ICMM mine closure guideline is used as the benchmark because Gold Fields is a member company along with the world's biggest mining companies. The expectation is thus that the guidance provided in the ICMM Mine Closure Toolkit would be used extensively across all mining sectors and geographies.

The focus of this research is on 'social' mine closure planning. Social mine closure planning considers the impact of closing a mine on local communities, employees and their dependents, interested stakeholders as well as authorities (Anglo American 2013). Contextual parameters such as location, local economic activities, mobility of individuals and skill levels, amongst others, fundamentally influences how mines may mitigate the impacts of mine closure (World Bank 2002). Determining mine closure impacts, the scale thereof and 
developing systematic ways in which a mine would avoid, minimise, mitigate and/or compensate for these impacts is a challenge. It is understood that social closure planning and implementation is an operational activity and budgeted for from operational budgets (Anglo American 2013). However, in the South African context, social closure related activities are typically left until the late operational phase of the mine's lifecycle as seen in the coal belt of Mpumalanga Province (Centre for Sustainable Mining and Industry 2010).

The objectives of this case study are to assess if South Deep mine has adequately considered and planned for social risks and impacts in its mine closure planning based on best practice guidelines and South African legislation.

\subsection{Methodology}

To meet the study objectives, the following methodology was followed. First a literature review was conducted of 1) the potential closure impacts on local communities, 2) the ICMM Mine Closure Toolkit as the best practice guideline, as well as 3) a review of specific mine closure legislation in relation to social closure.

Second was an assessment of the social closure considerations of South Deep's current mine closure and social and labour plans. Third was a gap analysis from a social closure perspective. This was to provide an understanding what the social closure gaps were in comparison to what is proposed by the ICMM closure toolkit and legislation.

To gain a deeper understanding of specific closure issues related to the South Deep mine, Gold Fields officials were interviewed as part of this study. In addition, academics and industry professionals were also interviewed to gain further insights into current debates on social closure planning (see Table 1).

Table $1 \quad$ List of interviews

\begin{tabular}{|c|c|c|c|}
\hline Name & Institution & Designation & Date of interview \\
\hline Allison Burger & Gold Fields & $\begin{array}{l}\text { Vice President: Head of } \\
\text { Community Relations }\end{array}$ & 28 February 2018 \\
\hline Caroline Digby & University of Cape Town & Adjunct Professor & 3 August 2017 \\
\hline Charlene Wrigley & Gold Fields & Mine Closure Specialist & 28 February 2018 \\
\hline Geralda Wildschutt & Gold Fields & $\begin{array}{l}\text { Community Relations } \\
\text { Consultant }\end{array}$ & 4 April 2018 \\
\hline Lochner Marias & University of the Free State & Professor & 18 April 2018 \\
\hline Tina Malau & Anglo American & $\begin{array}{l}\text { Community Development } \\
\text { Superintendent }\end{array}$ & 30 April 2018 \\
\hline
\end{tabular}

\subsection{Study limitations}

The South Deep operation was assessed based on information gathered from secondary sources as well as from interviews with Gold Fields officials, industry experts and professionals. The key limitations to the study are related to access to information, availability of information and shifting policy frameworks. Information on the surrounding mines is critical to assess whether South Deep's closure plan is adequate to deal with the social closure impacts. Sibanye-Stillwater's Cooke's mine, adjacent to South Deep mine, was placed under care and maintenance in terms of Section 52 of the Minerals and Petroleum Development Act 28 of 2002 (MPRDA) (Department of Mineral Resources [DMR] 2002) (see Section 3 for further details). One of the requirements on mines in terms of the MPRDA is that they should produce a social impact mitigation plan (SIMP), aimed at identifying and minimising the impacts of mine closure on employees and the local community. The SIMP for the Cooke's mine would thus provide insight to the actual impacts of mine closure on the local community; a community shared with South Deep. Despite an in-principle agreement by SibanyeStillwater's officials to cooperate in the study, challenges relating to the downscaling prevented officials from participating in the study. As such, no information from Sibanye-Stillwater was provided. 
The South Deep Decommissioning and Mine Closure Plan does not contain information on the quantum of the financial provision but rather, it references a separate report that outlines the financial provisioning calculation. Access to this report could be not provided, because the financial provisioning quantum was deemed confidential. As such, financial data on mine closure are inferred from the reports that have been provided. This limits the extent of the analysis on the financial provisioning aspects.

South Deep had entered a new social and labour plan cycle and the latest version of the social and labour plans (SLP) was submitted to the Department of Mineral Resources (DMR) for approval. This document was thus not publicly available and access to the final draft SLP submit was not provided. Information related to the SLP was therefore based on the 2013-2017 SLP.

\section{$2 \quad$ Literature review}

\subsection{Impacts of mine closure on communities}

Mine closure can be traumatic for communities, especially those in remote areas where the local mine has become the 'de facto' government due to weak local government structures. This trauma is exacerbated when non-mining productivity is low and labour mobility is limited (Marais 2013a).

Marais (2013a) provides an overview of the main social-economic consequences of mine downscaling and closure on local communities in the goldfields of the Free State Province, South Africa. There are seven broad consequences of mine closure on local communities reported. These are:

1. The creation of social instability and conflict in mine settlements.

2. Where municipal services are heavily subsidised by the mining company, social instability is exacerbated.

3. Impact of mine downscaling differs depending on the age, skills level, health and education of community members.

4. Post-mining communities have to endure ongoing environmental impacts of the closed mine.

5. Impact on various social and physical infrastructure.

6. Because of a deep dependency on mining companies developed over the life of the mine, communities have lost their sense of agency, self-help, and entrepreneurial spirit.

7. Loss of capital leading to out-migration.

It is recommended that the best way to mitigate mine closure impacts is to start planning for a post-mine economy once the mine opens (Anglo American 2013; Marais 2013a; World Bank 2002).

\subsection{Key elements of mine closure planning and ICMM toolkit}

The World Bank (2002), sets out typical elements that a mine closure plan should contain. These suggested elements have since been incorporated into various toolkits; one such toolkit being the ICMM Mine Closure Toolkit. The toolkit is not intended to be prescriptive but provides general principles around mine closure issues. It is also written from the perspective of an ideal situation, but it is still considered valid with a more realistic situation where no mine closure planning has been done for an operational mine.

The toolkit advocates for integration of mine closure practitioners from the various stages of the mine's lifecycle and between different disciplines of the mining company. Figure 1 below illustrates the closure planning process recommended by ICMM. 


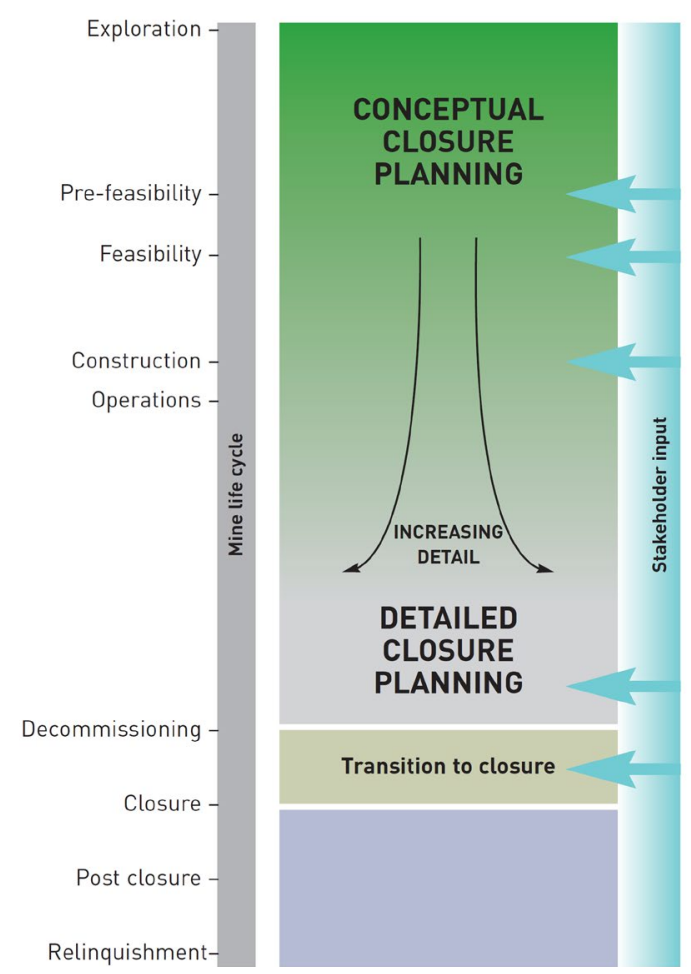

Figure 1 International Council on Mining and Minerals' mine closure planning process (ICMM 2018)

Ideally mine closure planning should start at the exploration phase. The rationale for planning from inception is that the earlier the risks and unknowns are identified, the greater the potential for meeting specific objectives. The ICMM toolkit suggests that there are three major steps in developing an effective closure plan. First, to develop the target outcomes and goals for closure which culminates in the conceptual closure plan. The second step is the iterative development and implementation of the detailed closure plan. Third, is the transition to closure which manifests in the decommissioning and post-closure plan.

It is noted that stakeholder expectations, including those of the community, will almost certainly change over time as will the mine plan, affecting operations as well as the life-of-mine. However, the specific outcomes and goals for closure may not have to change if they are defined well and in collaboration with other stakeholders. The specific activities of the detailed action plan will likely evolve with changing circumstances, highlighting the need for an iterative closure planning process.

\subsection{South African mine closure legislative review}

The South African mining industry is highly developed owing to its rich endowment of minerals and metals, but it is plagued with closure impacts that stem from over 6,000 ownerless and derelict mines (WWF-World Wildlife Fund for Nature 2012). In response, South Africa has developed a strong legislative framework for mine closure. Swart (2003) notes several closure scenarios. These include; closure, temporary closure (care and maintenance), abandoned mines, the selling of environmental responsibilities, derelict and ownerless mines, conditional closure, partial closure, closure under other regulations, as well as offshore closure. These scenarios, which come with varying degrees of social and environmental liabilities, burden governments with the responsibility of cleaning up the impacts associated with closure.

Several legislative acts govern the mining industry and the socio-economic and environmental impacts associated with mine closure. The key pieces of legislation reviewed as part of this study include the Constitution of South Africa; the MPRDA; the Mining Charter; MPRDA Regulations (GN R349 of 2011) (DMR 2011); the Mine Health and Safety Act 29 of 1996 (DMR 1996); the National Environmental Management Act 107 of 1998 (NEMA) (Department of Environmental Affairs [DEA] 1998); as well as the 2014 Environmental Impact Assessment Regulations (EIA) (DEA 2014). It is important to note that several other pieces of 
legislation exist that have a bearing on mine closure, for example, the Nuclear Energy Act, specific to gold mining, but these are not discussed as their relevance on 'social' mine closure is limited.

\subsubsection{South African Constitution}

The South African Constitution provides an overall framework within which to manage mine closure. Section 24b (iii), is clear that the environment needs to be protected for current and future generations and that natural resources should be used and developed sustainably to promote economic and social development (Republic of South Africa 1996). According to Liefferink (2017), this points to inter-generational equity in relation to environmental protection. This is especially pertinent in relation to post-mine closure land use, as well as mining related environmental impacts. Post-mining land use is one of the most critical issues related to closure (Liefferink 2017). Current communities may have benefited during the lifetime of the mining operation but unless the land is rehabilitated, the future generation may have their livelihood options limited or fundamentally damaged by a poor land use planning in the closure phases of a mine.

\subsubsection{Mineral and Petroleum Resources Development Act}

The MPRDA of 2002 has been hailed as best practice by the international community as it marked a paradigm shift in terms of rights and responsibilities of mining companies in South Africa (Marais 2013b). The main objectives of the legislation were to bring about redress of the mining industry from its Apartheid legacy ownership patterns, long-term environmental impacts and socio-economic conditions resulting from mining (DMR 2002). Section 41 of the MPRDA states that, as part of the mining right application process, an applicant should submit guarantees on financial provisioning for the remediation and management of negative 'environmental' impacts. This financial provisioning must remain in force until the Minister of the Department of Mineral Resources issues a closure certificate (DMR 2002). Section 43 of the MPRDA states that mining companies remain responsible for environmental liabilities, pollution or ecological degradation and the management thereof until the Minister has issued a closure certificate (DMR 2002). As the mine comes to the end of its lifecycle it may be placed under care and maintenance in terms of Section 52 of the MPRDA. During this period the mining company must have a care and maintenance plan which is annually audited and updated. Mining companies are also expected to produce a SIMP to mitigate the impact of downscaling. Labour and local mine community-related issues associated with closure are also addressed in the Mining Charter and SLP.

\subsubsection{Mining Charter III}

The revised Mining Charter, Mining Charter III, was released by the Minister of Mineral Resources in September 2018 after more than a year of negotiation between government and industry stakeholders. The vision for the Mining Charter is to facilitate transformation, growth, and development of the mining and minerals industry and the mission is to give effect to the relevant sections of the MPRDA and the Constitution (DMR 2017). The key sections related to social mine closure are those of ownership, mining community development, human resource development, preferential procurement as well sustainable development and growth. Mining Charter III requires a 30\% ownership of Black people which is to be comprised of eight percent of an Employee Share Ownership Program, eight percent to mining communities, and $14 \%$ to Black entrepreneurs. Black people are defined as any historically disadvantaged people in the Mining Charter III. A beneficiation offset, at a maximum, of $11 \%$ is permitted. The mining right holder must pay one percent of 'turnover' in any given financial year preferentially to Black shareholders. The shareholding of the mine community must be held in a trust created and managed by the Mining Transformations and Development Agency (MTDA). The Mining Charter III provides little insight as to when and how the MTDA will be established. The Mining Charter requirements, if complied with as intended to bring about lasting positive socio-economic benefits to host communities, can significantly influence social closure planning. 


\subsubsection{Social and labour plans}

The SLP is another mechanism employed to bring about socio-economic redress in the mining industry. Mining companies are required to submit an SLP as part of their mining right application and the SLP continues to be a requirement until a closure certificate is issued (DMR 2002, 2011). SLPs are supposed to integrate the local governments' integrated development plan and local economic development (LED) plans (Marais 2013b). The specific objectives of SLPs are:

1. Promoting employment and the advancement of social and economic welfare of all South Africans.

2. Transforming the mining industry in terms of ownership.

3. Socio-economic development of the areas in which mining companies operate and the major labour-sending areas (DMR 2011; Marais 2013b).

To fund the SLPs, companies are required to commit one percent of profit. However, with the new Mining Charter, this quantum may significantly increase with the expectation that mining companies are to commit one percent of revenue.

Section $46 \mathrm{~d}$ of the SLP guidelines relate to the process of managing downscaling and retrenchment. In anticipation of downscaling the mining company has to establish a 'future forum'. This forum brings key stakeholders together to discuss the impact of downscaling on the interested and affected parties and to reach agreement on the post-mining land use. The mining company is also required to develop mechanisms to save jobs and avoid a decline in employment as well as providing alternative solutions to create job security where losses cannot be avoided. In addition, it requires the mines to develop mechanisms to reduce the social and economic impact on individuals, regions, and economies where retrenchment or closure is a certainty (DMR 2011).

There is, however, no cross-reference between the requirements of the SLP in relation to downscaling and mine closure and the financial provisioning for the closure, creating room for interpretation (Caroline Digby, pers. comm., 9 April 2018). The extent to which mining companies make financial provision for social and economic impacts depends on their goodwill and corporate citizenship. This sentiment is reiterated by mining industry professionals.

"There is nowhere in the legislation that it states that money should be set aside for social mine closure activities, it only makes reference to environmental rehabilitation." (Tina Malau, 30 April 2018)

It is also important to note that the SLP is a mining operation requirement and it will remain relevant until a closure certificate is issued. The SLP is generally renewed every five years and, depending on whether the mine closure period coincide with the SLP cycle, a SLP may or may not be implemented once mining ceases. Practically, mining companies tend to address their social and economic liabilities through the implementation of an SLP pre- and post-closure (Tina Malau, pers. comm., 30 April 2018).

Despite high expectations to address negative socio-economic impacts of mining on local communities, SLP implementation has been criticised as being superficial and not addressing the real socio-economic impacts of mining by mining commentators as well as government. SLP have become glorified corporate social investment (CSI) programmes (Marais 2013b). The criticism levelled against SLP projects relates more to the quality and type of projects implemented as part of the SLP instead of enforcement; whether these projects address the current and closure social impacts of the mine.

Marias (2013b) notes that SLP guidelines are weak as pertaining to mine closure and downscaling because they mainly focus on employees and not impacts to the broader community. The DMR has expressed concerns about the long-term viability of SLP projects. The DMR has also found it difficult to assess the outcomes of the SLP projects (Marais 2013b). Other academics have also pointed to government's lack of capacity in monitoring and assessing the SLPs, leading to a high variability in SLP projects (Caroline Digby, pers. comm., 9 April 2018). 
From a mine closure planning perspective, the project-by-project nature of the SLPs, which are implemented over five-year periods, has resulted in projects which, by their nature, cannot address long-term and post-mining socio-economic impacts. Despite the criticism, other industry professionals believe that SLP's can be an effective tool for mine closure planning and implementation.

"If SLPs are designed and implemented in the spirit and intent in which they have been conceptualised, it could, in theory, work as a social closure planning instrument. However, with the current implementation of the SLPs, this is not the case. They are not designed with an obvious closure lens." (Geralda Wildschutt, 4 April 2018)

\subsubsection{Mine Health and Safety Act}

Sections 2 and 5 of the Mine Health and Safety Act (29 of 1996) stipulates the employer must ensure and maintain a safe and healthy environment for all phases of the mine including decommissioning and closure (DMR 1996; Swart 2003). Sections 12 and 13 pertain to medical surveillance and the requirement to track the health of employees exposed to hazards (Swart 2003). These medical records are to be kept until the mine closes, then it will be submitted to the Department of Labour. Section 17 pertains to exit certificates. An exit medical examination is a requirement for all employees. Each employee will be given an exit medical certificate which would indicate exposure to radiation, silica dust and noise as well as the presence of any occupational disease. The legislation is however silent on the latent onset of occupational diseases such as silicosis and former employees' rights in this regard.

\subsubsection{National Environmental Management Act}

The NEMA aims to address the issue of environmental protection as well as the social and economic development of mining areas (DEA 1998). The NEMA requires mining companies to make financial provisioning for rehabilitation, mine closure activities and remediation and management of latent or residual environmental impacts. The guidance provided by the Department of Environmental Affairs on how to calculate the financial provisioning, is very explicit on environmental and technical aspects of closure activities. Mine closure activities could be read to include socio-economic mine closure activities but in practice the focus tends to be on environmental and technical closure activities.

\subsubsection{Environmental Impact Assessment Regulations}

The EIA Regulations (DEA 2014) stipulate that in the development of the Environmental Management Programme (EMPr) and an Environmental Management Plan (EMP), mandatory as part of the mining right application, mining companies are required to evaluate the environmental, socio-economic and cultural heritage impacts. Interestingly, socio-economic impacts are bundled with environmental impacts in the EMPr and EMP, however, in the considerations and the determination of the mine closure financial provisioning, reference is only made to post-closure 'environmental' impacts and it is silent on social closure impacts. Further, the amended EIA Regulations (2014) stipulate the content of a closure plan and no reference is made to social closure (DEA 2014). The requirements of the EIA Regulations clearly spell out the responsibilities of mining companies in relation to environmental damage and pollution. Social aspects of mine closure are limited to public participation; the 2014 EIA Regulations it is required that interested and affected parties must be involved in determining the future land use (Liefferink 2017). It is ironic that impact identification in the EMPr and EMP include socio-economic and cultural heritage impacts. However, the costing of closure related activities that would mitigate these impacts during the downscaling and closure phase of a mine is not considered in determining the financial provision for the closure. In other words, socio-economic impacts are identified, but not costed for. 


\subsection{Challenges of social closure planning}

According to Caroline Digby, there is no such thing as best practice yet, when it comes to closure planning (Highgrade 2017). Social closure planning and implementation pose some additional challenges making it more difficult to deal with, compared to environmental and technical closure aspects.

Generally, there is a deep resistance to talk about closure. It is frightening for local communities, as it means the end of a stream of benefits from the mine (Highgrade 2017). It can also be very confusing for communities who have high demands and expectations for employment from the mine during the early stages of the mining lifecycle. There is a general lack of knowledge of social costs associated with mine closure and the timeframes required to build social and human capital are much longer than it may take to operate a mine (Digby 2016). The scale of closure planning tends to focus on individual mines instead of a multi-mine or regional approach. This individual mine closure planning approach ignores that environmental and social impacts are boundaryless.

"The SLP reporting system creates a system of individual planning. Regional mine closure is preferred." (Lochner Marais, 18 April 2018)

Social closure planning and implementation is not the sole responsibility of the mine. It involves many stakeholders; however, these stakeholders are not typically involved in social closure planning. Further, the roles and responsibilities of other stakeholders are not clear, and they may not have the capacity to meet these responsibilities.

Adequately planning for social closure requires assembling seemingly disparate stakeholder groups to first collectively imagine a post-closure future. Mining houses tend to have a paternalistic approach to planning solely relying on internal and consulting expertise to develop closure plans (Highgrade 2017).

More specifically in the South African context, social closure planning sits in the SLP, which is an operational instrument. There is no cross-reference within the legislation between closure planning stated in the MPRDA and social closure planning stated in the MPRDA regulations, specifically the SLP, the Mining Charter and NEMA; creating legislative loopholes for social closure planning (Caroline Digby, pers. comm., 9 April 2018).

Funding for the SLP is typically one percent of mine profits and as the mine draws to a close, so it experiences a decline in profitability, limiting the funds available for social mine closure implementation.

Many aspects related to social closure falls outside the ambit of social practitioners at the mines, such as Human Resources, property and estates, environment etc. For example, the SLP does not address issues related to redundant staff. The success of implementing the social closure plan depends to a degree on how well the people implementing the plan work together and understand how the various aspects of the closure plan inter-relate (Caroline Digby, pers. comm., 9 April 2018).

These challenges highlighted are not intended to be an exhaustive list but more to draw attention to the reasons why social closure planning is often not adequately addressed. In the following section the social closure planning effort of Gold Field's South Deep mine will be reviewed.

\section{Gold Fields and Sibanye-Stillwater case}

Gold Fields is a significant gold producer with an annualised production of 2.1 million gold equivalent ounces from six operating mines in Australia, Ghana, Peru and South Africa. South Deep mine is currently the only operating asset of Gold Fields in South Africa. Situated $45 \mathrm{~km}$ outside of Johannesburg, in the Gauteng Province, the economic hub of South Africa, it is easily accessed by the N12 national highway. Mining in the area dates back to the 1950's.

With a mineral reserve of 37.3 million ounces of gold, South Deep has an expected 75 -year life-of-mine. It contributed $13 \%$ to the Gold Fields' production in 2016. Its production increased to 290,000 ounces of gold in 2016 from 198,000 ounces in 2015. This resulted in a net cash flow of USD 12 million in 2016, a significant achievement from a negative USD 80 million net cash flow the previous year (Gold Fields 2017). 
In August 2017, Sibanye-Stillwater notified the DMR that it would be downscaling its Cooke operation, a gold and uranium mine, in terms of section 52 of the MPRDA, effectively placing the mine under care and maintenance, triggering retrenchments at the mine. The announcement of the retrenchment of 7,400 employees and potentially 3,000 contractors was met with significant opposition by the labour unions (Faku 2017). The Cooke mine is adjacent to South Deep mine, sharing the same local municipality and local communities. The potential negative social impacts stemming from the downscaling of Cooke was listed as one of the top 10 material risks to the South Deep Operation in Gold Field's 2016 Annual Report (Gold Fields 2017).

\subsection{Key socio-economic indices}

South Deep mine is located in what is now known as Rand West City Local Municipality (RWCLM) which is located within the Gauteng Province, South Africa's economic hub with Johannesburg as its capital city. The RWCLM was a merger of the Westonaria Local Municipality (LM) and Randfontein LM following the local elections in 2016. Both municipalities are in the West Rand District Municipality (WRDM). Given the 2016 merger of the local municipalities, all the secondary information sources provide data for the Westonaria and Randfontein local municipalities separately. For the purposes of this research paper, the former Westonaria LM will be the focus of the report because of the mine's location and the communities of the former Westonaria LM are in closest proximity to the mine.

Mining and manufacturing are the main economic activities contributing $39 \%$ and $16 \%$ to the local economy of the WRDM (South Deep 2013), followed by community service and finance sectors. Overall, the WRDM is the poorest district municipality in the region only contributing $4.6 \%$ to the local gross domestic product (South Deep 2013).

According to the 2011 census data, Westonaria has a population of 111,767 and 40,100 households. The gender ratio is skewed towards men at 120.8 for every 100 women. The young (0-14) constitute $24.5 \%$, the working population (15-65) $73.3 \%$ and the elderly (+65) $2.2 \%$ of the population (Statistics South Africa 2011).

There is a significant dependency ratio of $36.4 \%$ and an unemployment rate of $29.5 \%$. The youth unemployment rate is reported to be $39.3 \%$. The high unemployment rates are compounded by the low education levels in the Westonaria LM with $6.2 \%$ of people above the age of 20 having no education. Only $26.2 \%$ of the population completed high school and $5.3 \%$ have higher education. The percentage of people living in poverty in Westonaria is $40.3 \%$. The extent of poverty differs between the various race groups. In Westonaria $45.1 \%$ of Africans live in poverty, followed by $40.9 \%$ of Coloureds compared to $0.6 \%$ of Whites. There is, unfortunately, no data available for Asians (South Deep 2013).

Aside from high levels of poverty, unemployment and low education, the population of Westonaria LM does have access to basic services, although there is still room for significant improvement across all social indices. In Westonaria LM $42.2 \%$ have access to running water inside the household and $58.6 \%$ have access to a flush toilet. Pit latrines are the norm for $31.3 \%$ of the population. 59\% have access to formal housing and $69.4 \%$ have their refuse collected regularly and $64.3 \%$ of the population uses electricity for lighting purposes (Statistics South Africa 2011).

\subsection{Key social risks and expected impacts}

In 2016 Gold Fields undertook a risk assessment to identify the material risks across all Gold Fields operations. As an outcome of this study, each of the operations developed a community relations and stakeholder engagement strategy as well as a three-year plan focused on their social license to operate.

The top five risks identified for the South Deep operation in 2016 include 1) failure to achieve the South Deep operational/ramp-up plans and loss of investor confidence; 2) geotechnical risk; 3) labour relations; 4) Impact of the closure of Sibanye's Ezulwini (Cooke 4 shaft) on South Deep, and 5) regulatory uncertainty/Mining Charter delivery (Gold Fields 2017). Failure to achieve the operational/ramp-up plans and resultant loss of investor confidence continues to be the top risk for South Deep in 2018 (Gold Fields 2019). 
Other key risks identified, include the Thusanang informal settlement adjacent to the mine. The settlement has experienced rapid expansion from 121 households in 1998 to 3,500 households in 2011. The proximity of the Thusanang informal settlement to the mine fence poses a risk to the mine and the residents of Thusanang.

South Deep underwent a retrenchment process in 2018, a Section 189 process under the South African Labour Relations Act. Approximately 1,084 employees and 420 contractors were retrenched. To mitigate against the risk associated with the closure of the Cooke 4 shaft, South Deep was involved in ongoing engagement with Sibanye-Stillwater (Gold Fields 2017). Gold Fields has entered into a strategic partnership agreement with Sibanye-Stillwater to identify risks and impacts shared by the companies to work on a collective vision for the area. The broad intent of this agreement is to manage the impacts on local communities and to ensure that the development projects implemented by various stakeholders are aimed at the same end point and has positive impact on the local community (Geralda Wildschutt, pers. comms., 2 May 2018). Gold Fields reinvigorated this partnership with Sibanye-Stillwater in 2018, to close out legacy projects from the 2016 Gold Alliance as well as to align social investment projects to maximise benefit to their shared host communities (Alison Burger, pers. comms., 28 February 2018)

To build trust and productive relationships with the local community, Gold Fields in an alliance with SibanyeStillwater constituted a Round Table stakeholder engagement platform in 2016 which includes representatives from local government and community groups. The objective is to discuss socio-economic development in host communities. The composition of the Round Table includes the two mining companies, the WRDM, RWCLM, the South Deep Community Trust, the South Deep Education Trust and the Stakeholder Forum which represents the local community (Geralda Wildschutt, pers. comm., 2 May 2018). Three sessions of the Round Table discussions were held in 2018.

\subsection{South Deep socio-economic development and corporate social investment spend}

The drive for shared value creation is of strategic importance to maintain social licence to operate. The shared value programme focused on host community employment and procurement. Gold Fields state that they are dedicated to employing local community members provided that it is feasible based on the skills available. If not, they state that they are committed to local education and skills development (Gold Fields 2017). From a mine closure perspective, the focus on shared value projects like that of education and business development will likely decrease dependency on the mine over time.

At the group level, USD 26 million was spent on social investment projects in 2018. The socio-economic development (SED) spend for South Deep, inclusive of the SED spend by the community trusts, was ZAR $46.1 \mathrm{~m}$ (USD $3.49 \mathrm{~m}$ ). The two community trusts have, in addition, spent ZAR $21.5 \mathrm{~m}$ on various community projects, with the bulk spent on education (Gold Fields 2019).

\subsection{South Deep mine closure planning}

Effective closure planning and implementation is dependent on the synergies between various planning documents and policies, such as, inter alia, Mining Charter compliance, SLP and mine closure plans. It is important to note that SED and CSI programmes also have an important bearing on closure planning and implementation as these have a deep influence in determining the level of dependency host communities have on the mine. This section will assess specific mine closure planning documents of South Deep.

\subsubsection{Mining Charter compliance}

All mining rights holders are required to submit an annual compliance report to the DMR on the progress made in meeting annual targets in the Mining Charter. South Deep reviewed its 2018 Mining Charter performance against the Mining Charter II (2014) criteria and undertook a gap analysis against the Mining Charter III (2018) criteria. Gold Fields scored beyond compliance against all but two indices, where the associated projects are ongoing but nearing completion (South Deep 2018). 
The relevant elements from a closure planning perspective are mine community development and sustainable development and growth. In terms of sustainable development and growth, South Deep has implemented $100 \%$ of its approved Environmental Management Programme (EMPr). South Deep is also ISO 14001 certified which assists in tracking performance against its EMPr. In addition, the mine undertook an EMPr performance assessment in 2018 which was submitted to the DMR.

\subsubsection{South Deep SLP}

Aspects related to social closure sits within the SLP in compliance with Regulation 46(d) of the MPRDA. The assessment of South Deep's social closure planning will be based on their 2013-2017 SLP as the draft 2018-2022 SLP is still pending approval from the DMR.

The key elements of the social and labour plan in relation to mine closure planning would be human resource development, procurement, LED, management of downscaling and retrenchment as well as financial provisioning.

Under the 2013-2017 SLP cycle, South Deep spent approximately ZAR 750m on various SLP commitments. At South Deep, the host community procurement spend was ZAR $518 \mathrm{~m}$ (USD $39 \mathrm{~m}$ ), $29 \%$ of total procurement ahead of the $20 \%$ target. The host community definition changed to include all the residents of RWCLM which resulted in an increase in the percentage of host community employees to $55 \%$ (2,569 employees). All but two LED projects were completed in the current SLP cycle. A total of ZAR $4.8 \mathrm{~m}$ was spent on LED projects in 2018 (Gold Fields 2019).

In terms of the management of downscaling and retrenchments, South Deep established a 'future forum' in conjunction with organised labour in 2017 in line with legislative requirements. The future forum consists of management representatives, workers, and their labour union representatives. According to the mine union engagement strategy, the future forum is to meet monthly to discuss issues related to skills development, employment equity, the social and labour plan/future forum (South Deep 2014). South Deep's union engagement strategy makes no specific mention of mine closure planning, but it is likely that this is implied, and discussions will be triggered when a need arises. In respect to a mechanism to save jobs or avoid job losses in the context of downscaling, there is an over-reliance on the future forum in the SLP. The primary focus of future forum is the employees and their dependents and much less so on the impact of mine closure on the broader community.

\subsubsection{Final decommissioning, rehabilitation and mine closure plan}

The mine closure plan which was finalised in 2018 is designed to be an iterative document to be updated and refined periodically throughout the life of the mine. In relation to social closure, the mine closure plan references the SLP as the primary instrument to implement the social closure. The closure plan states that future updates of the LED projects of the SLP should take into consideration sustainability at closure and the SLP should be aligned with the closure plan. It is recommended that land use planning should be defined throughout the operation of the mine, considering stakeholder expectation and LED. The implication is that social closure planning should successfully develop alternative post-mining livelihoods. Social closure should also ensure that communities and local government become self-reliant and decrease dependency on the mine over time. It is suggested that a social closure strategy is developed that empowers communities, local government, and the regulators so that livelihoods are sustained following the withdrawal of the mine. The development of the social closure strategy would also take into consideration the management of the workforce. It would work to ensure the alignment of expectations of all stakeholders as well as the alignment of local and regional planning.

The closure scenario is formulated to provide the ideal context envisaged in which decommissioning and closure activities will occur. For the social aspects the closure scenario formulated include: an updated SLP for South Deep will be in place; there will be infrastructural transfer agreements in place and the third parties who will take transfer will have had appropriate capacity building and training; the local economic programmes will be entrenched aimed at self-sustaining livelihoods post-closure; mine employees would be 
re-skilled to pursue alternative employment opportunities and a wide range of economic opportunities would be established.

Post-mining land use zones have been identified based on the land use assessment and the biophysical characteristics of the site. The most likely post-mining land use options identified include pasture for grazing, ecological conservation areas and a conservation and wildlife rehabilitation. It is believed that this land use mix is the best option to achieve the overarching land use objective. Which is, "a sustainably functioning site that will contribute positively to the long-term ecological, economic and societal context" (Golder \& Associates 2018).

Unlikely post-mining land uses identified include industrial activities, extended re-use of existing mine plant by other mines, residential/mixed-use development and large-scale tourism.

It is recognised in the mine closure document that input from the local community, local and national government, non-governmental organisations are essential to determine the closure outcomes (Stacey et al. 2010 in Golder \& Associate, 2018). Furthermore, relationships between stakeholders and the company is an important factor in determining the extent to which stakeholders are involved in mine closure planning. The objectives of stakeholder management in relation to mine closure planning centre around stakeholder engagement. The Group's Mine Closure Guideline promotes engagement on mine closure with internal and external stakeholders throughout the life of the mine. It recommends that this engagement be transparent and constructive so that stakeholders may assist in the identification, assessment and management of significant environmental, social, and economic impacts associated with a mine closure and that they may participate in the determination and planning of the post-mining land use (Golder \& Associates 2018). The mine closure plan recommends that a targeted stakeholder communication and engagement strategy for post-mining land use and closure be developed (Golder \& Associates 2018). Despite the rhetoric, no formal mine closure-related engagement has yet taken place.

In addition, it is a recommended that regional closure planning be encouraged for it is recognised that it is not possible for mines to close effectively independent of its neighbours (Golder \& Associates 2018). The risk assessment does not include social risks related to mine closure. However, environmental risks such as soil contamination, or surface and groundwater contamination are important from a socio-economic perspective. Should these potential impacts materialise, it could significantly undermine the efforts to promote agriculture as a viable alternative economic activity. Furthermore, the environmental risks identified does not explicitly identify climate change impacts as a risk to rehabilitation. This would impact soil and water conditions as well as environmental resilience and recovery, further impacting the viability of agriculture as an alternative. As such climate change adaptation should be built into the successive closure plans.

The long life-of-mine in itself is considered to be a residual risk as the closure requirements could be distinctly different from the current requirements.

\section{Social closure gap analysis}

The lack of a shared vision for post-closure land use is probably the biggest weakness of the mine closure plan. To create a lasting benefit from the presence of Gold Fields in Westonaria LM, the local community should have influence over decisions which fundamentally impact their lives. This is not to say that involving stakeholders - local communities, businesses, government and other interested-is easy. How we frame and start the conversation on mine closure fundamentally impacts people's mindset and attitudes to mine closure (Highgrade 2018). It will certainly be a challenge to delicately balance the inherent tensions that arise from differing interests including the interest of current and future host communities. However, only when a shared vision is developed can all the actors start working together to leverage current mining related activities to create a future state that will ultimately have a positive and lasting legacy. Furthermore, the future forum has no representation from external stakeholders. In its current composition, the future forum is ineffective in addressing the social risks associated to mine closure. Perhaps the Round Table established 
is a more effective 'future forum' from a social closure perspective. There are a number of social closure gaps in relation to the ICMM guidelines highlighted in Table 2 below.

Table 2 South Deep closure plan gap analysis

\begin{tabular}{|c|c|}
\hline ICMM recommendation & South Deep closure plan \\
\hline $\begin{array}{l}\text { Integration of closure practitioners from one phase } \\
\text { to the next. }\end{array}$ & $\begin{array}{l}\text { Partial gap. There is no evidence in the closure plan } \\
\text { that refers to handover planning from the } \\
\text { operational team to the mine closure team. } \\
\text { Organisational capacity is referenced in the mine } \\
\text { closure planning document, noting the roles and } \\
\text { interaction between the Gold Fields Group, } \\
\text { Regional and Site teams with respect to closure } \\
\text { planning and implementation. }\end{array}$ \\
\hline Integration between external stakeholders. & $\begin{array}{l}\text { Gap. No reference is made to include other } \\
\text { stakeholders in the implementation of the mine } \\
\text { closure plan. However, reference is made to the } \\
\text { importance of consulting with external } \\
\text { stakeholders. }\end{array}$ \\
\hline Develop decommissioning and post-closure plan. & $\begin{array}{l}\text { Gap. The decommissioning and post-closure plan } \\
\text { has not yet been developed based on the } \\
\text { information provided in the mine closure plan. }\end{array}$ \\
\hline Draft mine closure engagement plan. & $\begin{array}{l}\text { Gap. It is understood that no mine closure } \\
\text { engagement has taken place. Further, there is no } \\
\text { evidence of a specific mine closure engagement } \\
\text { plan or strategy is in place for internal or external } \\
\text { stakeholders. }\end{array}$ \\
\hline $\begin{array}{l}\text { Identify external stakeholders related to mine } \\
\text { closure planning and implementation. }\end{array}$ & $\begin{array}{l}\text { Gap. Stakeholder identification would form part of } \\
\text { a mine closure strategy and plan. }\end{array}$ \\
\hline Conduct a mine closure risk assessment. & $\begin{array}{l}\text { Partial gap. A risk assessment has been conducted } \\
\text { for residual environmental risk but not for social } \\
\text { risks. However, a material risk assessment has been } \\
\text { done in relation to the closure of Cooke mine. This } \\
\text { is a good proxy for social closure impacts from } \\
\text { South Deep. These risks would need to be included } \\
\text { in the social mine closure plan. }\end{array}$ \\
\hline $\begin{array}{l}\text { Engagement with external stakeholders to identify } \\
\text { mine closure goals. }\end{array}$ & $\begin{array}{l}\text { Gap. No specific mine closure engagement has } \\
\text { been done to date. }\end{array}$ \\
\hline $\begin{array}{l}\text { Develop monitoring and evaluation (M\&E) } \\
\text { programme. }\end{array}$ & $\begin{array}{l}\text { Partial gap. A monitoring and evaluation } \\
\text { programme forming a part of the mine closure plan } \\
\text { and has been developed for environmental closure } \\
\text { plan, but not for social closure components. }\end{array}$ \\
\hline Action plans developed for M\&E. & $\begin{array}{l}\text { Gap. The action plans are to be developed closer to } \\
\text { the closure phase. }\end{array}$ \\
\hline Probabilistic assessment of mine closure costs. & $\begin{array}{l}\text { Partial gap. Mine closure costing for environmental } \\
\text { and technical components are well developed but } \\
\text { not for social closure components. }\end{array}$ \\
\hline $\begin{array}{l}\text { Confirm relinquishment of mine with the local } \\
\text { authorities. }\end{array}$ & $\begin{array}{l}\text { Unknown. There are no clear guidelines from the } \\
\text { DMR on what the relinquishment criteria for the } \\
\text { mining industry, evident by the paucity of mine } \\
\text { closure certificates issued to date. }\end{array}$ \\
\hline
\end{tabular}




\section{Discussion}

\subsection{Legislation: a key driver in mine closure planning}

Mine closure planning has a significant influence on the legacy of mining. If done poorly, it brings into question the overall benefits of mining to society. In the South African context, poor mine closure planning and outcomes, risk impacting the constitutional rights of local communities who are left with impacted environments.

The costing and planning for a closure tend to be focused on environmental and technical aspects of closure as the requirements and the responsibilities of the mining companies are clear under the environmental laws. Compared to the social and economic aspects of closure, where the legislation is implicit, most companies tend to stick to the minimum legal requirements instead of a more holistic interpretation of the intent of the laws and regulations. To a degree, this is understandable as it is not clear where to pin the responsibility for certain social closure impacts. For example, it is unclear where the responsibility lies to develop the post-closure economy of an area. This debate is however moot, as it does not decrease social risks associated with mine closure on the mining company.

Closure planning is thus effectively driven by environmental legislation due to the large-scale environmental risks associated with mine closure. The social aspects tend to be mentioned at a high level at best and it is primarily captured in the SLP regulations, which gives some guidance on social closure planning. The lack of explicit cross-reference relating to the social closure requirements under the SLP, the MPRDA and NEMA it creates legislative loopholes for social closure planning.

It is widely recognised the social closure planning and implementation are activities that need to happen concurrently in the operational phase of the project. Costing for social closure is therefore also seen as part of operational costs. LED projects included in the SLPs have been criticised to be a glorified Corporate Social Responsibility (CSR) project, nothing but wish lists with little coherence to the social impacts that are brought about by mining activities. The funding for the implementation of the SLP is based on the profitability of the mine, but at the end of the life-of-mine, when the mine is no longer profitable, funding for social closure activities is limited. This fundamentally impacts the ability of the mine to adequately meet its social closure responsibilities. It is further compounded by the fact that social closure activities are not included in the financial provisioning.

An SLP is required until the DMR provides the mining company with a closure certificate. It seems that with the legislative opacity in relation to social closure planning, the DMR is relying on this requirement to force mining companies to take greater cognizance of social closure impacts. Social closure planning thus manifests in the submission of the final SLP prior to the closure which is between five and three years before the closure. The SLP as a social closure planning and implementation tool, thus proves to be wholly ineffective.

\subsection{South Deep current social closure planning}

The social closure component of the SLP is written in a way that suggests that the detailed closure plan will likely only be finalised once the company enters the care and maintenance phase. By this time, it is too late as they may have already created significant social and economic liabilities. In discussion with company personnel, the social closure has gained far greater prominence in the company due to the closure of Sibanye-Stillwater's Cooke mine. It is reported that going forward the social closure consideration will be applied in the selection of LED projects (Geralda Wildschutt, pers. comms., 2 May 2018).

A key part of managing downscaling is the formation of the future forum. In its current composition, it seems like the future forum was established solely for compliance reasons as there are no representatives from the community or local institutions, rendering it ineffective to deal with any social mine closure issues other than employee-related issues. Many of the mine workers are from other regions and will likely leave the area once mining stops; compared to community members including vulnerable groups, local suppliers, and the local municipality who will be left behind. 
The lack of a shared vision is probably the biggest weakness of the mine closure plan. To create a lasting benefit from the presence of Gold Fields in Westonaria LM, the local community should have influence over decisions which fundamentally impact their lives. This is not to say that involving stakeholders such as local communities, businesses, government etc. is easy. It will certainly be a challenge to delicately balance the inherent tensions that arise from differing interests, including the interests of current and future host communities. However, only when a shared vision is developing can all the actors start working together to leverage current mining related activities to create a future state that will ultimately have a positive and lasting legacy.

\subsection{Potential role of mining companies}

To adequately plan for and implement social closure the mindset of all stakeholders in relation to mine closure has to change. Mine closure is not the responsibility of the mine alone, as such many stakeholders have to be involved in the planning and implementation thereof. This is not to dismiss the technical solutions of mine closure planning, but the challenge lies in the non-technical management aspects of mine closure planning.

Given the power, wealth and resources wielded by mining companies, their responsibility would be to be an influencer and facilitator to bring all the parties together to plan for life after the mine. If not, negative legacy of mining companies will persist, bringing into question the overall cost and benefits of the industry at large.

From a shared value perspective, mining companies are best placed to take on this facilitator role because it is in their interest to ensure that dependency decreases, and stakeholders are empowered to play their role in the closure planning and implementation. It is this empowerment that will create a positive legacy so that people, government, and the economy can leverage mining in the overall development of an area much the same as we see in countries like Japan and Norway.

\section{Conclusion}

In conclusion, the interplay of the relevant mine closure legislation clearly steers South Deep and the mining industry to have an environmental focus in their mine closure planning and implementation. With the SLP as the primary instrument to bring about social closure planning, it means that practically social closure tends to be given serious consideration, at best, five years before closure, effectively discounting social closure. At this late stage, the opportunities to significantly reduce social and economic closure liabilities have been missed. South Deep complies with all its legislative requirements and in terms of mine closure planning it has met best practice standards by developing a detailed closure plan early in the operational phase, but these do not adequately address the social risks and much more is required from a social closure planning perspective. South Deep's opportunity lies in its long life-of-mine whereby work is done now to build capacity and empower other stakeholders to take greater ownership in planning their future. However, this long life of a mine also poses a real risk of complacency.

It is hoped that if mining companies take on a facilitator role by bringing the relevant stakeholders together in developing a shared vision for a post-mining future early on in the operational phase, social closure planning will be far more robust, despite the current legislative loopholes. There is real potential to develop a best practice model.

\section{Acknowledgement}

This research paper stems from my research report in partial fulfilment of my Masters in Business Administration degree from the International University of Japan. I am truly grateful to Gold Fields for enabling this study, in particular, Naseem Chohan, Allison Burger, Puseletso Matete and Geralda Wildschutt. Your support has been invaluable! I am also deeply grateful to the industry professionals interviewed as part of this study, especially Caroline Digby, Tina Malau and Lochner Marais who provided helpful insights to the topic. Finally, I thank my supervisor, Professor Hyunkoo Lee, who helped me navigate my research. 


\section{References}

Anglo American 2013, Mine Closure Toolbox, version 2, Johannesburg, https://www.angloamerican.com/ /media/Files/A/AngloAmerican-Group/PLC/sustainability/approach-and-policies/environment/mine-closure-tool-box/toolbox-main-brochure-Ir.PDF

Centre for Sustainable Mining and Industry 2010, The Socio Economic Aspects of Mine Closure and Sustainable Development: Literature Overview and Lessons for the Socio-economic Aspects of Closure, Johannesburg, viewed 30 May 2019, http://www.wrc.org.za/wp-content/uploads/mdocs/SP\%2071\%20The\%20Socio\%20Economic\%20Aspects\%20of\%20Mine\% 20Closure\%20and\%20Sustainable\%20Development\%20Vol\%201\%20-\%202010.pdf

Department of Environmental Affairs 2014, National Environmental Management Act (107/1998), Amendments to the Environmental Impact Assessment Regulations, Government Gazette 3822, Pretoria.

Department of Environmental Affairs 1998, National Environmental Management Act 107 of 1998, Government Gazette 37170, Pretoria.

Department of Mineral Resources 2017, Broad-based Black Socio-economic Empowerment Charter for South African Mining and Minerals Industry, Government Gazette, Pretoria.

Department of Mineral Resources 2011, Minerals and Petroleum Resources Development Regulations (GNR349), Government Gazette 34225, Pretoria.

Department of Mineral Resources 2002, Minerals and Petroleum Resources Development Act 28 of 2002, Government Gazette 23922, Pretoria.

Department of Mineral Resources 1996, Mine Health and Safety Act 29 of 1996, Government Gazette No. 967, Pretoria.

Digby, C 2016, Mine Closure \& Rehabilitation: From Dereliction to Accountability?, Centre for Environmental Rights Seminar on Mine Closure, viewed 23 May 2018, https://cer.org.za/wp-content/uploads/2016/05/Prof-C-Digby-5.5.2016.pdf

Faku, D 2017, Retrenchment Bloodbath as Sibanye Gold Aims to Chop 7400 Jobs, Business Report, viewed 23 May 2018 , http://www.iol.co.za/business-report/companies/retrenchment-bloodbath-as-sibanye-gold-aims-to-chop-7400-jobs10628519

Gold Fields 2017, Integrated Annual Report 2016: Year of Growth, Gold Fields, Johannesburg.

Gold Fields 2019, Integrated Annual Report 2018, Gold Fields, Johannesburg.

Golder \& Associates 2018, South Deep Gold Mine, A Division of GFI SA (Pty) Ltd: Final Decommissioning, Rehabilitation and Mine Closure Plan for South Deep, Gold Fields, Johannesburg.

Highgrade 2017, To Close a Mine - RAW Talks with Caroline Digby [video file], retrieved from https://www.youtube.com/watch?v=HVbXWymG7Ss

International Council on Mining and Metals 2008, Integrated Mine Closure: Toolkit, viewed 1 August 2019, http://www.ibram.org.br/sites/700/784/00001524.pdf

Liefferink, M 2017, 'Mine Affected Communities: Risks, Expectations and Opportunities', Science Business Society Dialogue Conference, Johannesburg.

Marais, L 2013a, 'The Impact of Downscaling on the Free State Goldfields', Urban Forum, issue 24, pp. 503-521.

Marais, L 2013b, 'Resources Policy and Mine Closure in South Africa: The case of the Free State Goldfields', Resources Policy, issue 38, pp. 363-372.

National Resources Governance Institute 2014, National Resource Charter, 2nd edn, viewed 4 June 2019, https://resourcegovernance.org/sites/default/files/documents/nrcj1193_natural_resource_charter_19.6.14.pdf

Republic of South Africa 1996, Constitution of the Republic of South Africa, Act 108 of 1996, Pretoria.

South Deep 2013, South Deep Mine Social and Labour Plan 2013-2017, Gold Fields, Johannesburg.

South Deep 2014, Union Engagement Strategy, internal company document, Gold Fields, Johannesburg, unpublished.

South Deep 2018, South Deep Social and Labour Plan 2018-2022, Gold Fields, Johannesburg.

Statistics South Africa 2011, Westonaria Local Municipality, viewed 25 April 2018, http://www.statssa.gov.za/ ?page_id=993\&id=westonaria-municipality

Swart, E 2003, 'The South African Legislative Framework for Mine Closure', The Journal of the South African Institute of Mining Metallurgy, vol. 103, issue 8, pp. 469-492.

World Bank 2002, It's not over when it's over: Mine Closure Around the World, World Bank, Washington DC.

WWF-World Wildlife Fund for Nature 2012, Financial Provisions for Rehabilitation and Closure in South African Mining: Discussion Document on Challenges and Recommended Improvements, Cape Town, viewed 19 May 2018, http://awsassets.wwf.org.za/downloads/wwf_mining_8_august_low_res.pdf 